\title{
Potential of Transforming Sodalite from Synthesis Kaolin with a Mild Condition of the Hydrothermal Method
}

\author{
Norsuhailizah Sazali 1 ${ }^{(1)}$, Zawati Harun 1,* (D), Tijjani Abdullahi ${ }^{1}$ (D) , Faiz Hafeez Azhar ${ }^{1}$, Azlinnorazia \\ Ahmad ${ }^{1}$, Nurul Izwanie Rasli ${ }^{2}$, Norazlianie Sazali ${ }^{3}$ (D) \\ 1 Advanced Materials and Manufacturing Centre (AMMC), Faculty of Mechanical and Manufacturing Engineering, \\ Universiti Tun Hussein Onn Malaysia, 86400, Parit Raja Batu Pahat, Johor, Malaysia; suhailizah@gmail.com (N.S); \\ zawati@uthm.edu.my (Z.H); abdulltj@gmail.com (A.T); faizhafeezazhar@gmail.com (F.H.A); azlinnorazia@gmail.com \\ (A.A); \\ 2 Faculty of Applied Sciences and Technology, Universiti Tun Hussein Onn Malaysia, Pagoh Education Hub, 84600, Muar, \\ Johor, Malaysia; wanie.rasli@gmail.com (W.S.); \\ 3 College of Engineering, Universiti Malaysia Pahang, 26300 Gambang, Pahang, Malaysia; azlianie@ump.edu.my (N.S.); \\ * Correspondence: zawati@uthm.edu.my (Z.H.);
}

Scopus Author 57192717612

Abstract: The hydrothermal synthesis method is one of the successful methods for transforming kaolin into sodalite with various parameters considered. The variation of alkalinity source of 2-3 Molarity of sodium hydroxide and crystallization time (12-16 hours) was considered an important parameter that influences the formation of sodalite. It is reported in this research that the process of synthesizing sodalite to transform into an amorphous stage (Metakaolinization phase) began with beneficiation of kaolin to remove the impurities and calcination by $650^{\circ} \mathrm{C}$ for four hours. The synthesis was done through an aging process $\left(40^{\circ} \mathrm{C}, 24\right.$ hours), and the crystallization temperature was $100^{\circ} \mathrm{C}$. The kaolin was characterized by XRD, FESEM, FTIR, PSA, TGA, followed with metakaolin by XRD, FESEM, FTIR, and the end-product by XRD, FESEM, FTIR, and PSA. The crystallinity percentage of sodalite slightly increased by increasing the molarity and crystallization time, but quartz remains in the end-product.

Keywords: kaolin; metakaolin; sodalite; hydrothermal method; amorphous

(C) 2021 by the authors. This article is an open-access article distributed under the terms and conditions of the Creative Commons Attribution (CC BY) license (https://creativecommons.org/licenses/by/4.0/).

\section{Introduction}

Sodalite [SOD] can be identified as an idealized zeolite framework [1]. Sodalite is a microporous crystalline tectosilicate with a general composition of $\mathrm{Na}_{8}\left[\mathrm{AlSiO}_{4}\right]_{6}[\mathrm{x}]_{2}$, where $\mathrm{x}$ is the guest anion monovalent [2]. Sodalite $\left(\mathrm{Na}_{8}\left[\left(\mathrm{Al}_{6} \mathrm{Si}_{6} \mathrm{O}_{24}\right)\right] \mathrm{Cl}_{2}\right)$ has a three-dimensional structure of a "cage"[3] that can naturally contain halogen salts. Sodalite can be natural or synthetic, much like zeolite. To explore their crystal chemistry and properties, synthetic counterparts are manufactured on an industrial scale for specific uses or prepared in a laboratory [1,2]. For purposes of definition, another part of the zeolite community excludes sodalites from the class of zeolite-type structures. SOD has a framework density of 16.7 T/1000 $\AA^{3}$ and is thus an open framework since it comprises only 4- and 6-rings. The zeolite group usually finds zeolites only open frameworks with an n-rings aperture of $n>6$ [4] as a "semicondensed" tetrahedral framework structure. Despite the classification problem, sodalite [SOD] belongs to a class of crystalline microporous tetrahedral network structures that span a 3D framework enclosing void of at least $2.5 \AA$ diameters [5]. From Linus Pauling's seminal 
work on the X-ray structure determination of the mineral sodalite [6], the structural details of sodalite have been known for about 75 years.

To produce a range of materials with specific and industrially attractive properties, sodalites can be modified. Hydrosodalite, $\mathrm{Na}_{6}\left[\mathrm{AlSiO}_{4}\right]_{6} .8 \mathrm{H}_{2} \mathrm{O},[7,8]$ with anion at the center of the cage substituted by water molecules is a sodalite alteration. Therefore, only three sodium ions per cage are required to counterbalance the charge on the aluminosilicate structure. The cubic structure of hydrosodalite is $a=8.9 \AA$. The structure and properties of various cationexchanged hydrosodalites $(\mathrm{Li}, \mathrm{K}, \mathrm{Mg}, \mathrm{Ca})$ prepared with the appropriate metal nitrate by ion exchange of $\mathrm{Na}_{6}\left[\mathrm{AlSiO}_{4}\right]_{6} .8 \mathrm{H}_{2} \mathrm{O}$ [9] have been investigated. SOD has a cubic structure containing only $\beta$-cages consisting of eight alternating $\mathrm{AlO}_{4}$ and $\mathrm{SiO}_{4}$ tetrahedra 6-membered rings and six 4-membered rings; the free dimension of the inscribed $\beta$-cage sphere is $6.6 \AA$, and access to the cage is $\sim 2.2 \AA$ [10] through the 6-membered ring window (channel).

For its potential application, sodalite has attracted considerable attention, such as optical material [11], waste management [12], hydrogen separation [13], and catalyst support [14]. Natural sodalite mainly holds chloride anions in the cages, but they can be substituted with other minerals in the sodalite group representing end-member compositions, such as sulfate, sulfide, hydroxide, trisulfur, etc. Some natural mineral materials have been used for sodalite synthesis. For example, by the solid transformation of $\mathrm{Al}_{2} \mathrm{O}_{3}$ pillared clay in the alkaline solution, nano-sized sodalite crystal was obtained [15-16], perlite [17] was transformed by the alkaline hydrothermal method into a micro-sized sodalite crystal or sphere. Among other sources of sodalite natural mineral material, kaolin material containing predominantly kaolinite appears to be a more promising substance for sodalite synthesis because it consists of high $\mathrm{Si}, \mathrm{Al}$ as the key sources of zeolite synthesis; is cheap and also easy to be obtained in Malaysia.

Kaolinite has its chemical formula, $\mathrm{Al}_{2} \mathrm{Si}_{2} \mathrm{O}_{5}(\mathrm{OH})_{4}$. Other minerals can exist in kaolinite, such as quartz, illite, mica, feldspar, and other impurities [18]. The bonded $\mathrm{SiO}_{4}$ tetrahedral sheet and bonded $\mathrm{Al}(\mathrm{OH})_{4}$ octahedral sheet construct the structure of kaolinite, which means that the octahedral and tetrahedral sheets are in repeated stacking orders [19]. Kaolinite has a crystal tri-clinic system and a layer of $7.13 \AA$ units. The bonding is weak between the units, but the bonding is strong between the repeating units. Kaolin clay is very easy to spread in [20] since it has a low heat conductivity hydrophilic feature and a pH scale is between $t$ 4-9. When undergoing the process of metakaolinization, the features of kaolin cause it to be very reactive. Metakaolinazation is a mechanism where the hydroxyl group is lost, and a chemical transition occurs while the kaolin is heated at a certain temperature level. Calcination rearranges the octahedral layer to the tetrahedral layer [21]. The temperature and time of calcination differ, and this step makes the layer of arrangement very unstable. A temperature of between $550-600^{\circ} \mathrm{C}$ is normally selected, and the process becomes more stable before $900^{\circ} \mathrm{C}$, but at $1050^{\circ} \mathrm{C}$ [22], the mullite process will occur. The factors for checking the suitability of kaolin to be transformed into zeolite [22] are the location and geological phenomena of kaolin. Usually, the hydrothermal technique is used for sodalite, hydrosodalite, and zeolite synthesis.

Hydrothermal synthesis, which is the mild critical reaction and the supercritical reaction, can be divided into two categories. The temperature from $100^{\circ} \mathrm{C}$ to $240^{\circ} \mathrm{C}$ is used for the mild critical reaction, while the supercritical reaction can exceed $1000^{\circ} \mathrm{C}$. Zeolitic products are typically synthesized by alkali activation of an aluminosilicate, and the phase of the compound is highly influenced by the processing conditions used. The following processing 
conditions have been shown to support hydrosodalite over the formation of other zeolitic phases: synthesis time between 24 and 72 h [23]; solid: liquid ratios > 5 [24]; NaOH solution concentrations $>3 \mathrm{M}$ and synthesis temperatures between 150 and $200{ }^{\circ} \mathrm{C}$ [25]. Hydrothermal synthesis is by far the most commonly used method [25], while more complex methods of twostep synthesis involving alkaline pre-fusion at elevated temperatures have also been used [26]. It is also normal for calcining kaolinite to form metakaolin by heating above $600{ }^{\circ} \mathrm{C}$ in order to improve reactivity prior to synthesis [27]. Synthesis routes typically use an excess amount of $\mathrm{NaOH}$ solution, even for hydrosodalite that prefers low solid: liquid ratios [23], which makes them incompatible for extrusion processing. This technique is often used for ceramic production. Given that both calcination and mid-temperature synthesis involve an additional heating step, a low-temperature synthesis route without thermal pre-treatment could be desirable for energy reduction and practicality. Previously, the proportion of stages of the kaolinite reaction with sodium hydroxide was investigated in relation to the nature of the kaolinite used [28] or the addition of different volumes of activating solution at the given $\mathrm{pH}$ [29]. Although proof of concept for non-hydrothermal synthesis has been shown by HellerKallai and Lapides[30], a systematic understanding of the reaction has not previously been established for these conditions. A lower temperature and atmospheric synthesis path will make processing cheaper and consume less energy.

In this study, sodalite was synthesized from low-grade Johor kaolin with a Molarity of $\mathrm{NaOH}, 2-3$, and 12-16 hours of crystallization time at $100^{\circ} \mathrm{C}$ temperature. They were characterized from kaolin, metakaolin, and sodalite using XRD, FESEM, FTIR, TGA to see the transformation from kaolin to sodalite.

\section{Materials and Methods}

\subsection{Material.}

At Jemaluang, Mersing, Johor, a Johor kaolin sample was obtained. The raw kaolin collection site was the venue where the mining operations took place. The raw material of kaolin needs a pre-treatment process because of the greater lumpy size condition. The lumpsize kaolin must be extracted by crushing and grinding. A ball milling machine is used for crushing the lump-size kaolin during this process. The beneficiation process will further treat the crushed kaolin. The primary purpose of the raw material undergoing beneficiation was to increase and improve kaolin's physical and chemical properties. $3 \mathrm{~kg}$ of crushed kaolin was soaked in a 15-liter container which contained 10 liters of distilled water for one week. The soaked kaolin was regularly mixed. The positive result of the gain was that, after stirring, the kaolin would settle. The floating soil was decanted along with the supernatant, and all solid particles were collected by handpicking during decantation. The continuation of this approach has ensured that no solid layer at the bottom of the container existed. The fine particles suspended in water were dried for one day at room temperature and then sifted using a 63micron mesh. The sieve particles were then kept for 12 hours in a drying oven. The kaolin raw material collected from the recipient phase was subsequently analyzed and distinguished by physical and chemical components. The Qre company was responsible for providing the sodium hydroxide. 


\subsection{Synthesis procedure.}

The kaolin was placed in the crucible for the metakaolin process and heated for 4 hours in the oven at a temperature of $650{ }^{\circ} \mathrm{C}$ [31]. Approximately $3 \mathrm{~g}$ of metakaolin was weighted and steadily combined in a beaker with the $2 \mathrm{M} 60 \mathrm{~mL} \mathrm{NaOH}$ dilution solution. The work of Chandrasekhar and Pramada [32] was the basis of the composition of the prepared reaction mixture. The mixture was stirred for 24 hours at $40{ }^{\circ} \mathrm{C}$ for the aging process. The mixture was mixed in an enclosed place to avoid evaporation. After aging, the solution for the crystallization process was instantly moved to the $100 \mathrm{~mL}$ Teflon line autoclave. $100{ }^{\circ} \mathrm{C}$ temperature was chosen for the crystallization process with different interval times (12 hr and $16 \mathrm{hr}$ ). Next, on a cold-water plate, the mixture will quickly cool down. At the end of the procedure, the supernatant was collected and washed until the $\mathrm{pH}$ was below 10 . In the end, the last solid remains were dried in the oven at $60{ }^{\circ} \mathrm{C}$ for 12 hours. Figure 1 shows the illustration of the hydrothermal method.
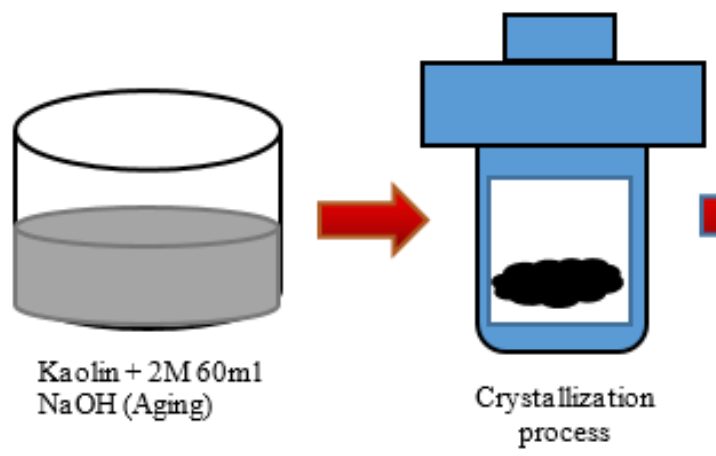

Cool, wash and drying

Figure 1. Illustration of the hydrothermal method.

\subsection{Characterization methods.}

The particle size analyzer by Mavern Mastersizer 2000 was used to measure the particle size of raw kaolin and synthesized zeolite. The characterization and phase material of all samples for this study used advanced XRD Bruker D8 with a $40 \mathrm{kV}$ scaled copper tube. Diffraction is the principal technique for characterizing zeolite. The sample was made up of powder. The angle selected for the diffraction of the sample was $2 \theta=10-90^{\circ}$. The powder was prepared at room temperature, and it was placed in the holder, making it smooth. The usage of XRD is usually meant to determine the presence of crystalline zeolite [33]. The XRD appeared as the unit cell parameter of the zeolite [34]. A special software (Xpert High score) and Rietveld fitting were used for the structural evaluation of the sample. For regulated atmospheres such as air and oxygen, TGA is a method of calculating changes in the weighted sample as a function of temperature and time. The TGA has many applications, including calculating thermal material and the moisture content of a material. For the purpose of this study, TGA analyzed the material composition and thermal stability of raw kaolin at room temperature until $1000{ }^{\circ} \mathrm{C}$ with a heating rate of $10^{\circ} \mathrm{C} / \mathrm{min}$ using nitrogen gas. The FTIR usage strategy is similar to XRD. FTIR calculated the vibration related to the external tetrahedral linkage and internal stretching of the tetrahedral structure. FTIR is widely used to classify chemical compounds. FTIR was conducted in the $400-4000 \mathrm{~cm}^{-1}$ range. Using FTIR, the power association of raw kaolin, metakaolin, and zeolite was investigated. Field emission scanning electron microscopy (FESEM) provided elementary and topographical information with unlimited depth at magnifications of 10x to 300 000x. A smoother image and less electrostatically blurred image will be created by FESEM compared to SEM. 


\section{Results and Discussion}

\subsection{Particle size analysis (PSA) of kaolin.}

After the beneficiation process, the dried kaolin sample was acquired for further analysis, and a $63 \mu \mathrm{m}$ mesh was used to sieve the sample. The particle size test was conducted three times with a 7 percent adsorption rate for each scan. The average produced will be improved, and more precise outcomes can be obtained. For Johor kaolin, the mean diameter reported at the end of the result was $712 \pm 0.2 \mathrm{~nm}$, as shown in Figure 2. The finding is tallied with Yahaya et al., [35], with a scale of 0.4-0.75 $\mu \mathrm{m}$ for the kaolin.

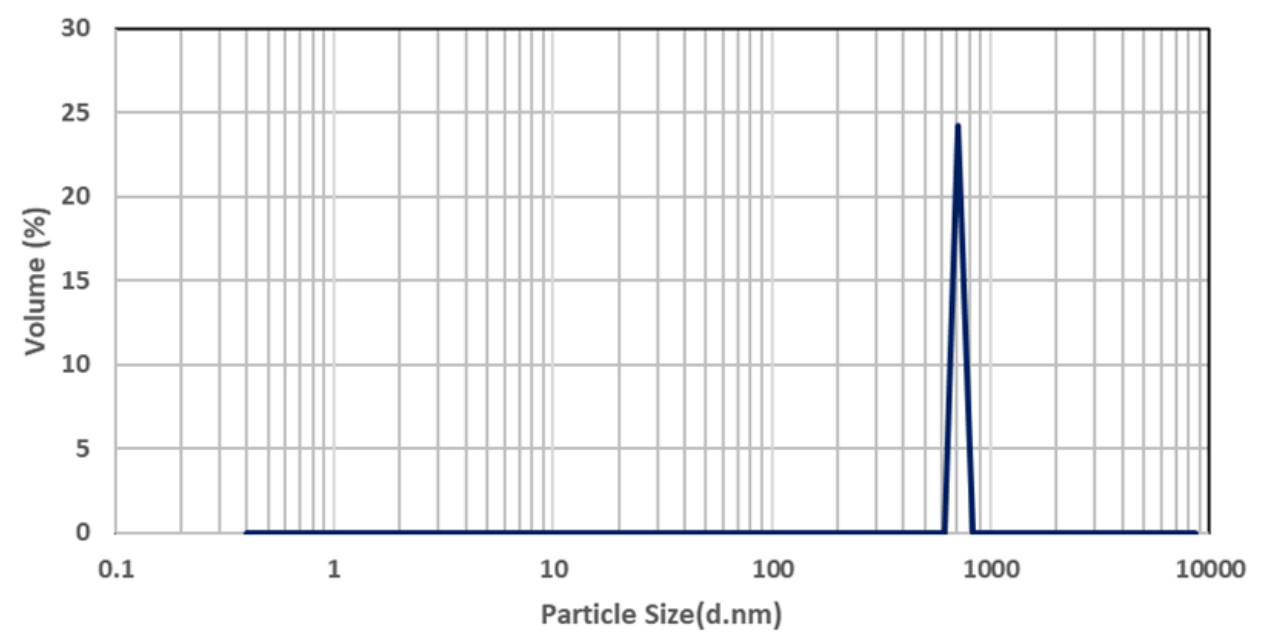

Figure 2. Particle size analysis of kaolin.

\subsection{X-ray diffraction analysis (XRD) analysis of kaolin.}

The findings of the mineralogical review of X-ray diffractogram (XRD) for Johor kaolin were consistent with those obtained by Chin et al. [36]. There may be variations in kaolin's percentage and mineral content due to the different areas of origin, albeit in the same state. In addition, the method of kaolin beneficiation provided a stronger outcome for further processing of kaolin into sodalite. A sharp plateau at $2 \theta=26.645$ for Johor kaolin is perfectly suggested for the quartz process with ICSD pattern number 98-001-7535, as shown in Figure 3. While the peak of kaolinite $1 \mathrm{~A}$ appeared at $2 \theta=12.402$ and 24.952 , referring to ICSD pattern number 98-001-2946.
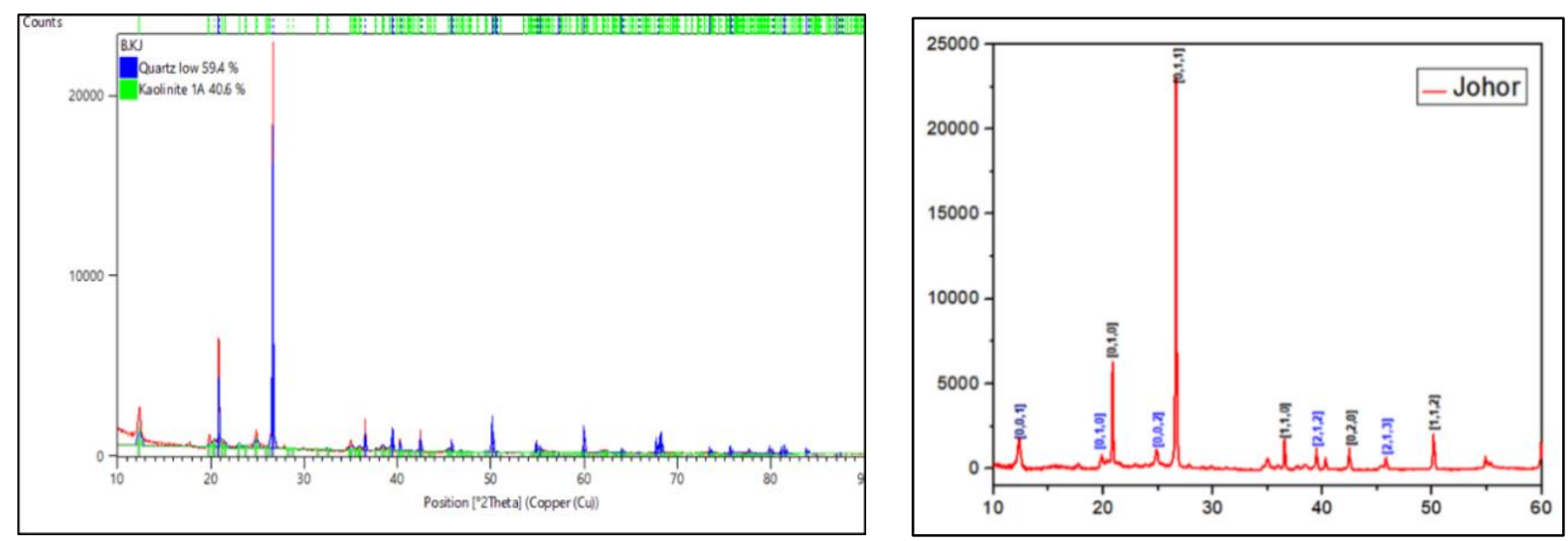

Figure 3. XRD analysis of kaolin. 
In kaolin samples, a relative similarity in peak positions was found, as seen in Table 1. For the reasons reported by Johor kaolin, the high percentage of quartz against kaolinite obtained from the XRD study is not far from the predicted percentage [37]. The geological composition of Johor kaolin, on the other hand, was dominated by metasediments from the early years of earth change [38], a repetitive series of mainly argillaceous rocks of very finegrained materials. In addition, the presence of kaolinite makes it possible to transform it into sodalite under the hydrothermal method.

Table 1. Position, peak intensity, miller indices, and phase analysis of Johor kaolin.

\begin{tabular}{c|c|c|c|c|c|c} 
No & $\mathbf{h}$ & $\mathbf{k}$ & $\mathbf{l}$ & $\mathbf{2}$ theta & Intensity (a.u) & Element \\
\hline 1 & 0 & 0 & 1 & 12.402 & 2791 & Kaolinite 1A \\
\hline 2 & 0 & 1 & 0 & 19.89 & 1204 & Kaolinite 1A \\
\hline 3 & 0 & 1 & 0 & 20.870 & 6703 & Quartz \\
\hline 4 & 0 & 0 & 2 & 24.952 & 1302 & Kaolinite 1A \\
\hline 5 & 0 & 1 & 1 & 26.645 & 21059 & Quartz \\
\hline 6 & 2 & 1 & 2 & 38.558 & 516 & Quartz \\
\hline 7 & 1 & 1 & 0 & 36.565 & 1868 & Quartz \\
\hline 8 & 0 & 2 & 0 & 42.475 & 1111 & Kaolinite 1A \\
\hline 9 & 2 & 1 & 3 & 45.668 & 372 & Quartz
\end{tabular}

\subsection{Field emission scanning electron microscopy (FESEM) analysis.}

Johor Kaolin's FESEM photos are shown in Figure 4. The typical structure of kaolinite was demonstrated in the FESEM photo. The raw kaolin clay revealed a layered crystalline morphology from the images that confirmed early studies by Ariffin et al. [38], Belviso et al. [39], and Baioumy [40] on kaolin Malaysia variation in mineralogy. Further micrograph analysis found embedded irregular platelets and poorly defined flakes containing sub-rounded particles in all samples.

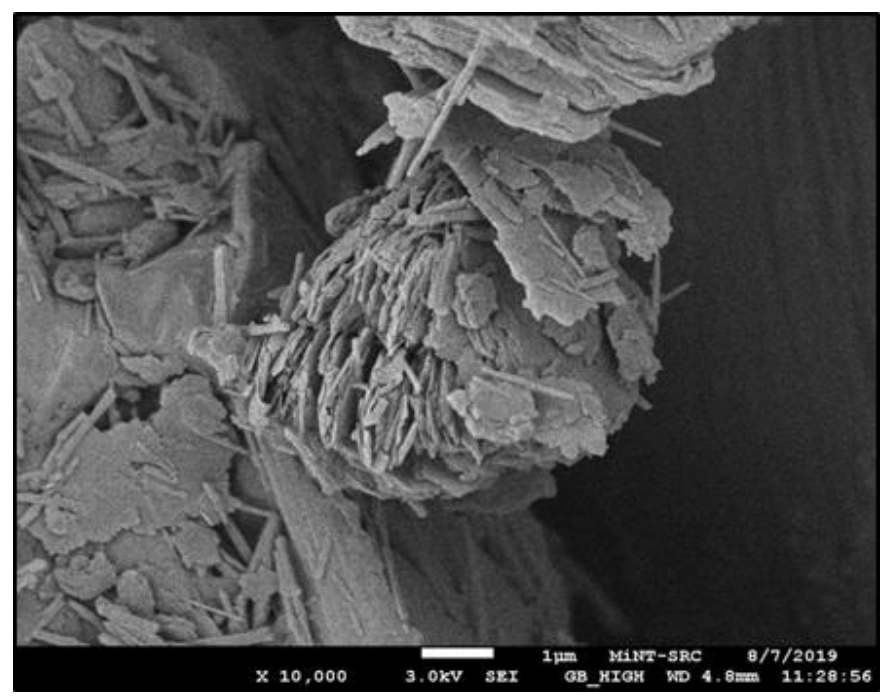

Figure 4. FESEM image of kaolin.

As seen in Figure 5, the findings were further confirmed on an EDX analyzer, demonstrating the presence of $\mathrm{Si}, \mathrm{Al}$, and $\mathrm{O}$ in the Johor kaolin sample as extreme peaks. More notably, in the Johor kaolin range, a moderately high Si peak with a much higher peak was found in both spectra. This finding substantiates, as shown in Figure 2, the result mentioned in the XRD diffractogram. The presence of Si indicates the silica content of the two clays of 
kaolin [41]. The highest recorded peak was attributed to the formation marked by a high quantity of quartz in the Johor kaolin.
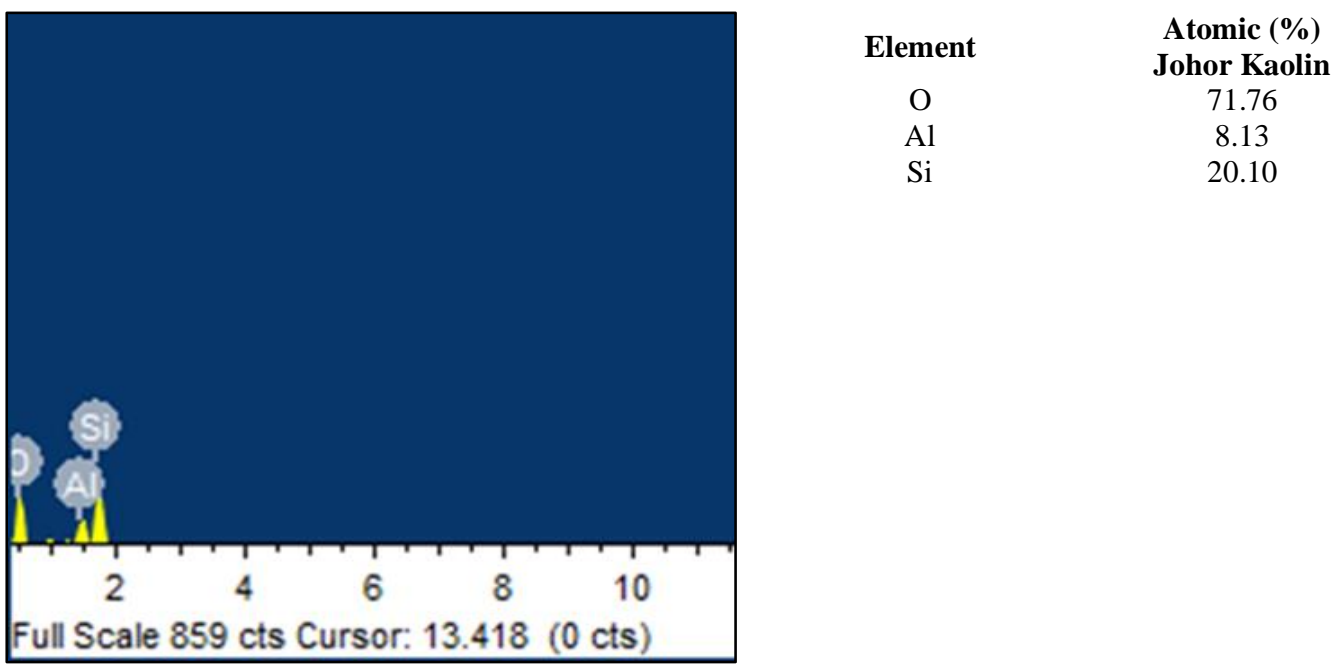

Figure 5. EDX analysis of kaolin.

The kaolin samples were collected from a secondary geological deposit formed in the presence of water due to alterations of aluminosilicate rocks [42]. There was a strong market for the presence of crystalline silica, better known as quartz, used in refractories and ceramic ware because it was a silica glass in its amorphous state [43]. On the contrary, the presence of quartz was a major drawback for the application of kaolin in the synthesis of zeolite, sodalite, and hydrosodalite, especially at a high percentage.

\subsection{Fourier Transform Infrared Spectroscopy (FTIR) analysis.}

The FTIR spectrum of the kaolin sample for Johor is shown in Figure 6. The spectrum $300-1300 \mathrm{~cm}^{-1}$ band region of kaolin clay was devoted to the molecular structure of kaolinite $[44,45]$. According to Kovo and Holmes [46], the starting Al-O bending mode was approximately $800 \mathrm{~cm}^{-1}$, equipped with the Johor kaolin vibration and bending mode. The SiO stretching was described at 460 to $700 \mathrm{~cm}^{-1}$, possibly the same as a previous study, which observed a sharp peak at $698 \mathrm{~cm}-1$ as Si-O [47]. Furthermore, Kovo and Holmes [46] identified the bands as Si-O stretching at $700 \mathrm{~cm}-1$ and $1033 \mathrm{~cm}-1$ while bands are located between 3610 and $3695 \mathrm{~cm}^{-1}$ due to hydroxyl groups [44]. However, the bands representing the Johor kaolin hydroxyl groups are 3615 to $3692 \mathrm{~cm}^{-1}$, suggesting the hydrophilicity property of most kaolin [44].

It has been proposed that the band of $1156 \mathrm{~cm}^{-1}$ is most likely to be from asymmetrical stretching vibration and symmetrical vibration of the Al-O-Si groups, respectively, based on previous studies [47]. At 700 to $800 \mathrm{~cm}^{-1}$, the vibrational bands were assigned to Si-O stretching, which corresponds to quartz, which was very small and diffused. This refers to the coincidence of the various forms of silicate molecular motions arising from different silicate minerals [48].

\subsection{Thermogravimetric (TGA) analysis.}

The TGA result for Johor kaolin is shown in Figure 7, which revealed that the kaolin samples were completely dried since there were no signs of hydration or preliminary stage dryness in the TGA curve. It was observed again in weight instead. This likely weight gain is 
probably not due to interaction with the furnace wall [49]. Still, it may be due to the reaction of the gaseous substances in the purge gas or to the possible adsorption of kaolin, the gaseous material in the sample.

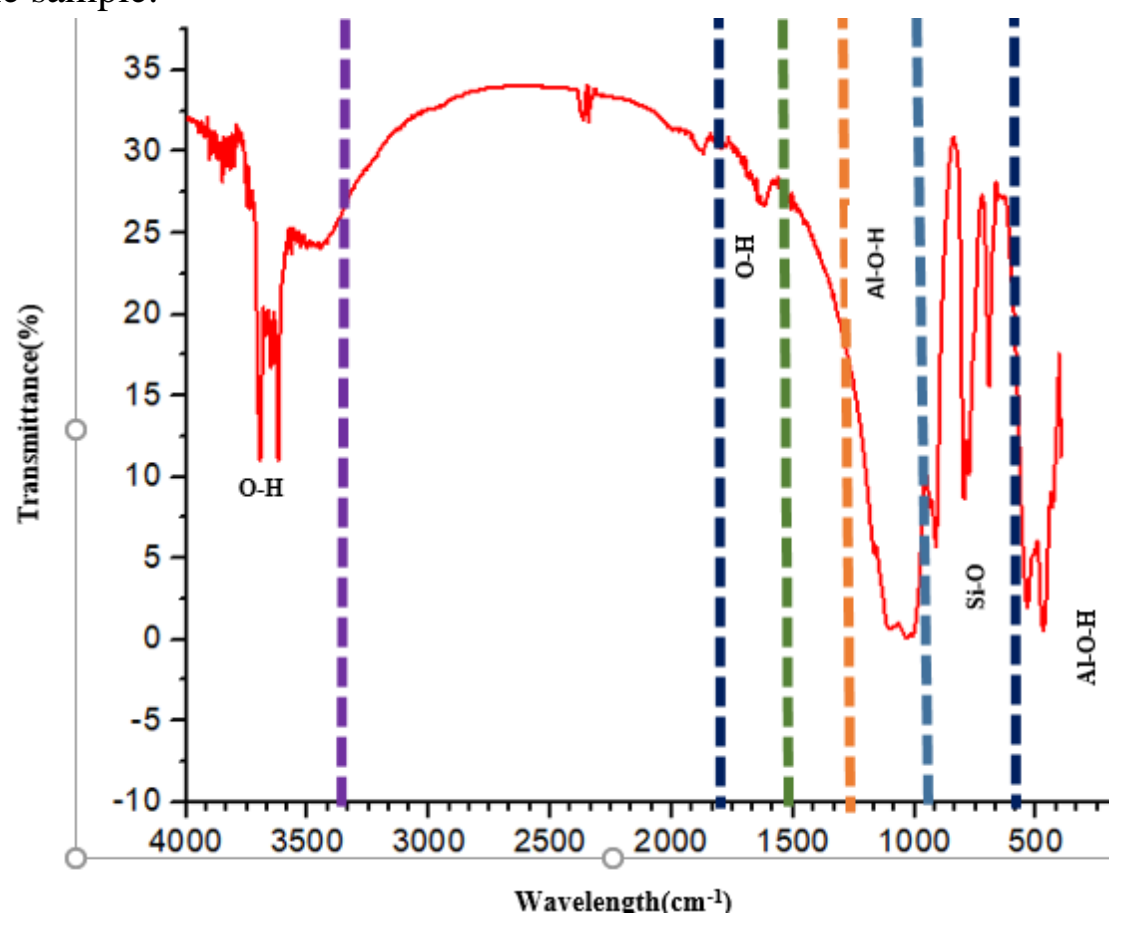

Figure 6. FTIR analysis of kaolin.

The original weight dropped by 1.4 percent in Johor kaolin, as the temperature rose to $342.63{ }^{\circ} \mathrm{C}$. The decomposition and loss of crystallization water were apparent as the heating temperature increased. The crystallization water varied mainly from the "pore water" typically lost at the drying point. Chemically mixed, crystallizing water formed an essential unit of the crystal structure of the kaolin. Johari et al. [50] suggested that kaolin crystallization water can only be impacted by temperatures above $400{ }^{\circ} \mathrm{C}$. The loss of crystallization water was induced at approximately $450{ }^{\circ} \mathrm{C}$, as seen in the Johor kaolin thermograms, signaling the beginning of the dehydroxylation reaction. When the heating temperature was raised to $525.88{ }^{\circ} \mathrm{C}$, a different weight reduction was reported, with a 6.1 percent weight reduction in Johor kaolin due to the structural loss of the hydroxyl group presented in the kaolinite layers, in conjunction with Kubiliute and Kaminskas [51].

From the TGA curve of the kaolin study, a dehydroxylation reaction of around 650 to $700{ }^{\circ} \mathrm{C}$ seemed to have been accomplished. If the heat temperature increases, a further occurrence that may lead to an exothermic reaction is predicted to occur, although this work is limited to the reaction that could lead to metakaolin (dehydroxylation). The substantial weight reduction in Johor kaolin, which occurred at $684.7{ }^{\circ} \mathrm{C}$, suggested that the mineral kaolinite decomposed into free alumina, silica, and water [51]. Johor Kaolin had a weight loss of 8.1 percent at this point. The findings of the TGA study were close to those of other kaolin clay studies [50, 52] but were fundamentally distinct from those [53] where dehydroxylation at 500 ${ }^{\circ} \mathrm{C}$ was achieved due to variations in the mineralogical composition of the examined kaolin. TGA research has specifically shown the weight shifts that characterized the occurrence of a chemical reaction. 


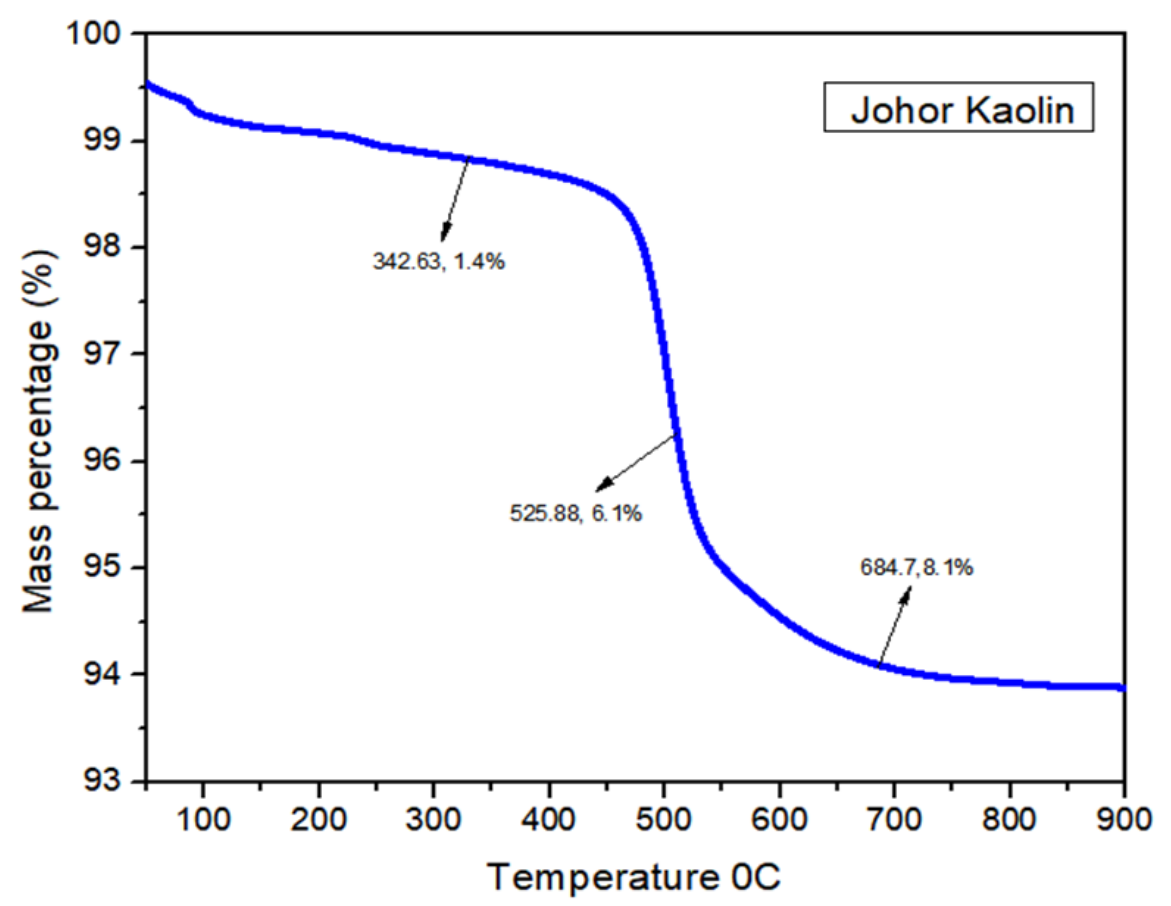

Figure 7. TGA analysis of kaolin.

\subsection{Metakaolinization.}

As seen in Figure 8, the result indicated the XRD analysis of the effect of the kaolin sample's metakaolinization on $650{ }^{\circ} \mathrm{C}$ over a 240 -minute duration with pure kaolin. For the treatment with $650{ }^{\circ} \mathrm{C}$, the obtained X-ray diffraction pattern showed a transition of kaolin to amorphous $\mathrm{SiO}_{2}$ due to a decrease in peak strength of kaolinite at $2 \theta=24.952$ for the kaolin. For this kaolin, the absence of kaolinite peak at $2 \theta=12.402$ and 24.952 positions showed that calcination is sufficient at this parameter. A major amorphization with significant removal of the kaolinite peaks and a notable presence of the amorphous $\mathrm{SiO}_{2}$ phases were also seen. This development was consistent with the results of Shafiq et al. [54], Kovo [55], and Feltrin et al., [56] and may simply be due to the differences in the quality, composition, and geological formation of kaolin materials.

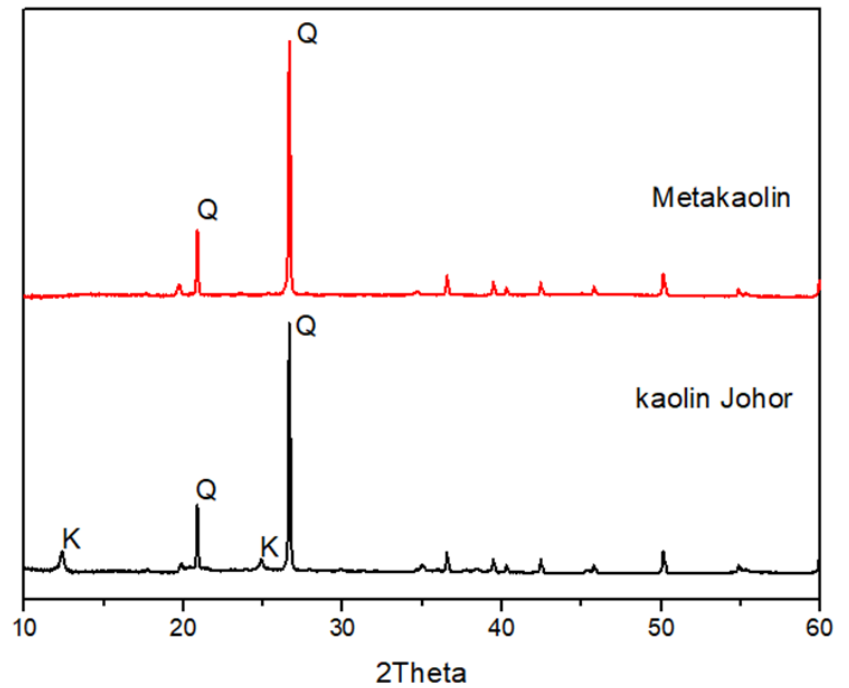

Figure 8. XRD analysis of kaolin and metakaolin. 


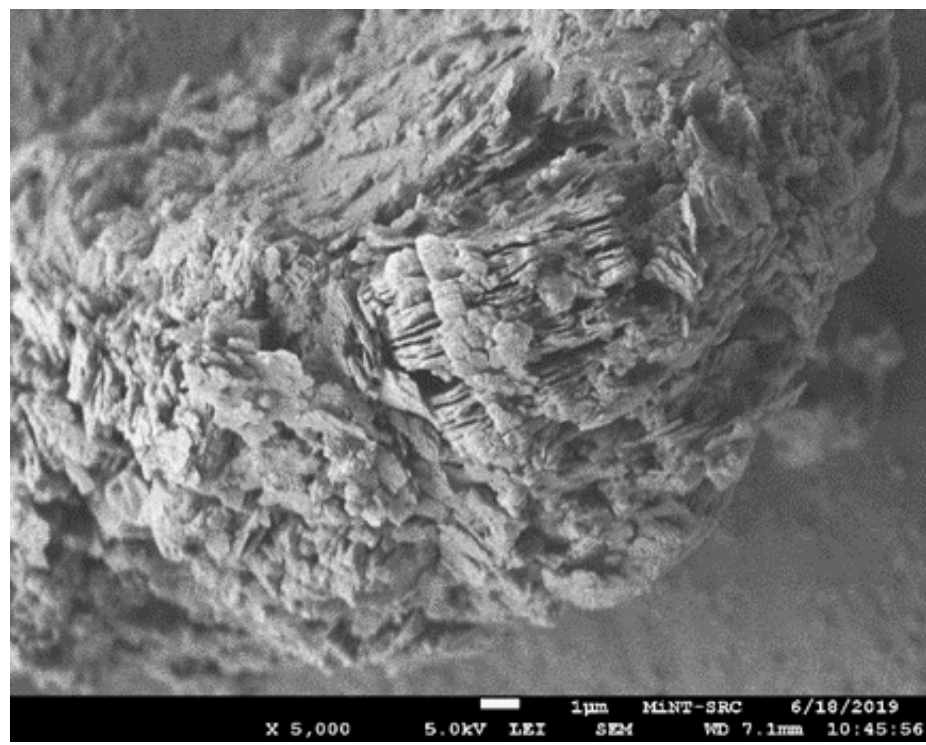

Figure 9. Fesem image of metakaolin.

Figure 9 showed a highly disordered metakaolin, characterized by a sheet-like morphology and a highly disordered and amorphous structure formed by calcination treatment. This finding was consistent with other research studies [57-60].

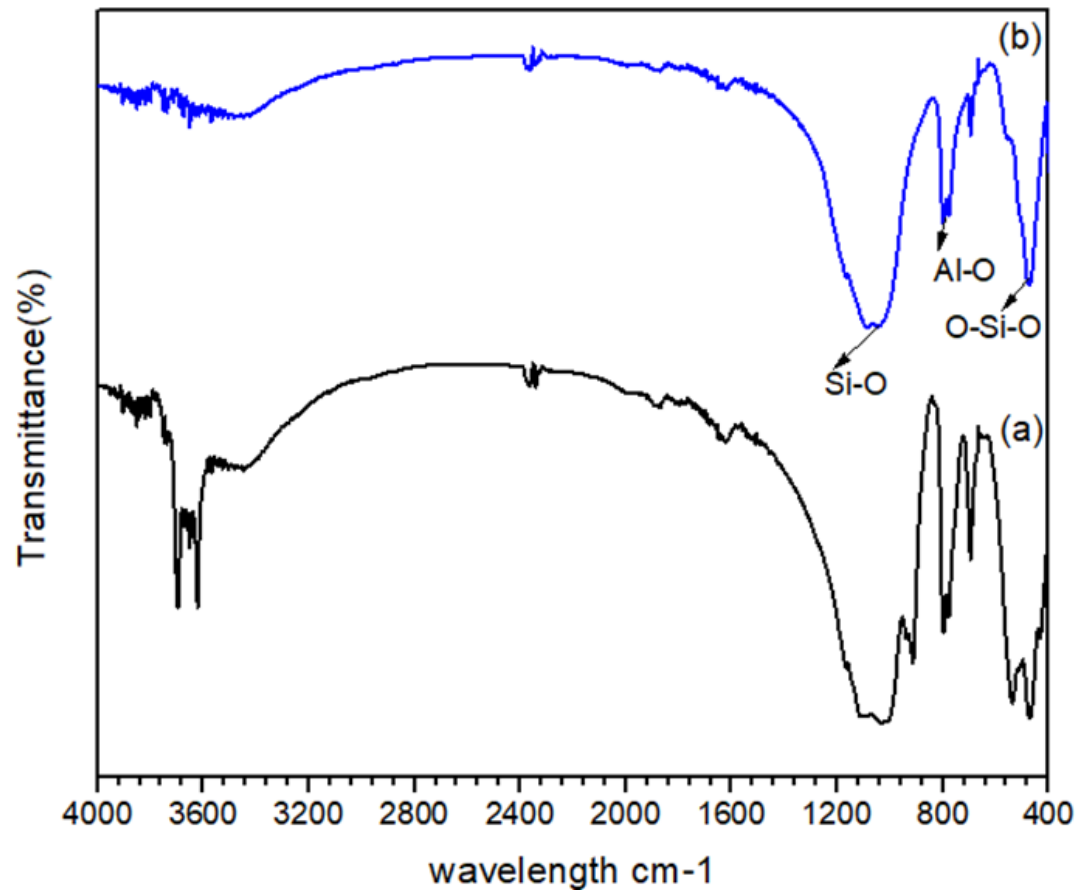

Figure 10. Comparison of FTIR analysis for kaolin and metakaolin.

From the FTIR result shown in Figure 10, the broad bands of the kaolin emerged from an exposure period of 240 minutes, which was not previously seen and is located at around 790 $\mathrm{cm}^{-1}$. This was assigned to the $\mathrm{Al}-\mathrm{O}$ bond in $\mathrm{Al}_{2} \mathrm{O}_{3}$, suggesting the creation of free alumina and the conversion with tetrahedral coordination of octahedral-coordinated $\mathrm{Al}$ to $\mathrm{Al}$ [61]. At $1085 \mathrm{~cm}^{-1}$, there was another wide shoulder that was delegated in $\mathrm{SiO}_{2}$ to stretching bonds. In metakaolin Johor, the broad shoulder peak was seen as the low percentages of quartz highly consisted of Johor kaolin reflecting $\mathrm{Si}-\mathrm{O}$ bonds. Again, this suggested the formation of free silica, as reported by Brindley et al. [62]. The $470 \mathrm{~cm}^{-1}$ bands have also been assigned to the 4-coordinated Al-O stretching in a metakaolinite structure [63]. The obtained bands typically showed the conversion of kaolinite to metakaolinite at $650{ }^{\circ} \mathrm{C}$ after vigorous heating. 


\subsection{Zeolite Synthesis.}

3.7.1. X-ray diffraction analysis (XRD) analysis.

The XRD result for the step quantification of synthesis kaolin with the same aging time, but the difference in molarity and crystallization time is shown in Figure 11. While, Figure 12 shows the different XRD analysis patterns for kaolin, metakaolin, and synthesis kaolin. Despite the same aging period used for kaolin, there was a different percentage of sodalite formation. From the XRD result in Figure 11, there was no percentage formation of sodalite using $2 \mathrm{M}$ $\mathrm{NaOH}$ and 12 hours of crystallization time. However, by increasing the molarity and crystallization time, sodalite and quartz are formed at $3 \mathrm{M} \mathrm{NaOH}$, sodium hydroxide with crystallization time of 12 and 16 hours, which was $28.8 \%$ sodalite and $29.5 \%$ sodalite, respectively.

The stirring process successfully improved the consistency of the gel mixture and altered the formation of zeolite phases [46] during the aging phase. This can be explained by the fact that the aging operation has created enough nuclei that allowed for enormous crystal growth of other phases at the cost of zeolite A, leading to a situation described as a standard zeolite crystal routine $[64,65]$.
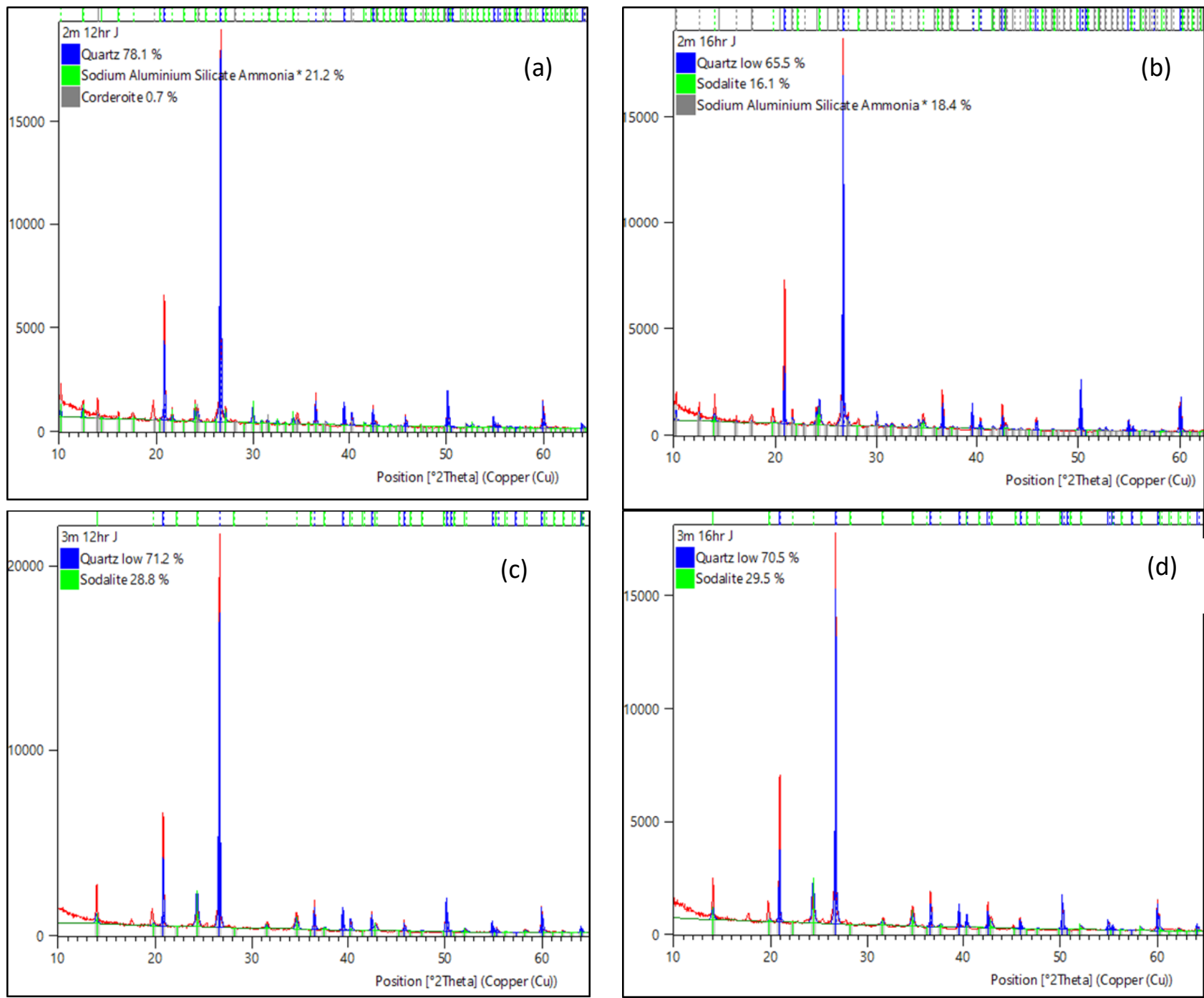

Figure 11. The comparison of XRD analysis for kaolin synthesis (a) 2M NaOH, 12-hour crystallization time; (b) $2 \mathrm{M} \mathrm{NaOH}$, 16-hour crystallization time; (c) $3 \mathrm{M} \mathrm{NaOH}$, 12-hour crystallization time; (d) 3M NaOH, 16-hour crystallization time. 


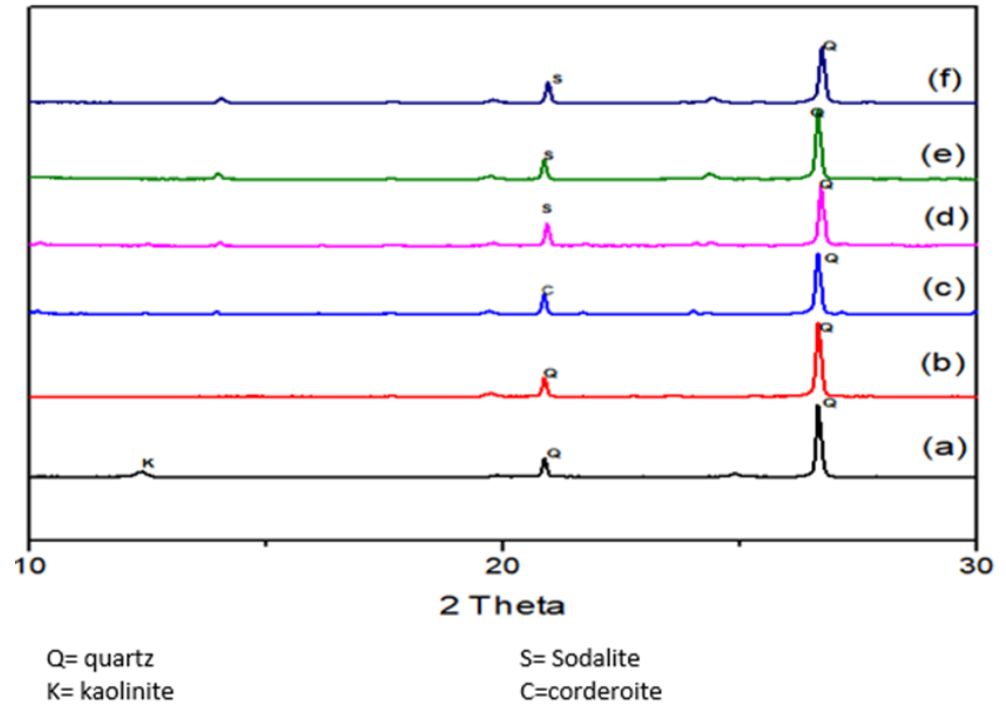

Figure 12. Different $\mathrm{X}$-ray diffractograms (a) kaolin; (b) metakaolin; (c) 2M NaOH, 12-hour crystallization time; (d) $2 \mathrm{M} \mathrm{NaOH}, 16$-hour crystallization time; (e) $3 \mathrm{M} \mathrm{NaOH}$, 12-hour crystallization time; (f) $3 \mathrm{M} \mathrm{NaOH}$, 16-hour crystallization time.

The forming of sodalite fitting to ICSD No 98-003-5795 was initiated during the $2 \mathrm{M}$ 16-hour crystallization process. The percentage of formation of sodalite was increased by increasing the molarity of $\mathrm{NaOH}$ and crystallization time. But, unfortunately, though the $\mathrm{NaOH}$ molarity and crystallization time was raised, the hydrothermal process used to turn kaolin into a strong adsorbent failed to turn the complete sodalite layer. This result indicated that differentiating the synthesis time contributed to the development of distinct types and purity of zeolite [66-69]. This effect also occurred because zeolite and sodalite were thermodynamically metastable steps in such a way that the synthesis mechanism was overpowered by the Ostwald phase rule of successive reactions. The earlier statement that zeolites are thermodynamically metastable phases was supported by this discovery, which was attributable to the substitution of phases at various crystallization times [70,71]. The variations in the composition of the raw kaolin, however, contributed significantly to this loss. Table 2 shows the different crystallinity percentages of sodalite formation on different crystallization times but the same molarity during the hydrothermal process. The result showed that the crystallinity percentage of sodalite was lower, under $50 \%$, as the percentage of sodalite in XRD analysis was low.

Table 2. Different crystallinity percentages of different molarity $\mathrm{NaOH}$ and crystallization time for Johor kaolin.

Kaolin

\begin{tabular}{|l|l|l|l} 
Reaction Parameter & \multirow{2}{*}{ Crystallinity (\%) } \\
\hline Aging & Molarity & Crystallization time & \\
\hline 24 hours & $3 \mathrm{M}$ & $12 \mathrm{hr}$ & 43.86 \\
\hline 24 hours & $3 \mathrm{M}$ & $16 \mathrm{hr}$ & 44.72
\end{tabular}

3.7.2. Fourier Transform Infrared Spectroscopy (FTIR) analysis.

Figure 13 displays the FT-IR spectrum of the starting materials and the synthesized products obtained after hydrothermal treatment with alkaline solutions. With reaction time, the typical vibration bands of the starting materials have disappeared. In general, the characteristic bands of the transmittance change starting materials to lower wavenumbers suggested that, as stated in other tests, there was more $\mathrm{Al}$ replacement in tetrahedral sites of the silica matrix with $\mathrm{NaOH}$ acting as a structure modifier. As seen in (Figure 13), the absorption bands of the synthesis products displayed the typical SOD asymmetric and symmetric vibration bands in 
the $1200-400 \mathrm{~cm}^{-1}$ region. Barnes et al. [72,73] summarized that the recorded assignments of vibrations for SOD should happen during this time. In the SOD system, the transmittance of the Si-O-Al asymmetric stretch consisted of a single band at $960 \mathrm{~cm}^{-1}$, [2] but this analysis recorded only the bands at 960 corresponding's to SOD. The presence of a mixture of SOD and CAN in the as-synthesized products is indicated by several bands in the $750-650 \mathrm{~cm}^{-1}$ region. The bands in area $500-420 \mathrm{~cm}^{-1}$ are aligned with the $\mathrm{Si}-\mathrm{O}$ and $\mathrm{Al}-\mathrm{O}$ internal tetrahedron vibrations of the zeotypes. As proposed in previous research, the area $800-400 \mathrm{~cm}^{-1}$ can be known as the fingerprint region of zeolite LTA, SOD, and CAN [74,75]. An example of the degree of crystallinity of the synthesis products is the FT-IR peak distance.

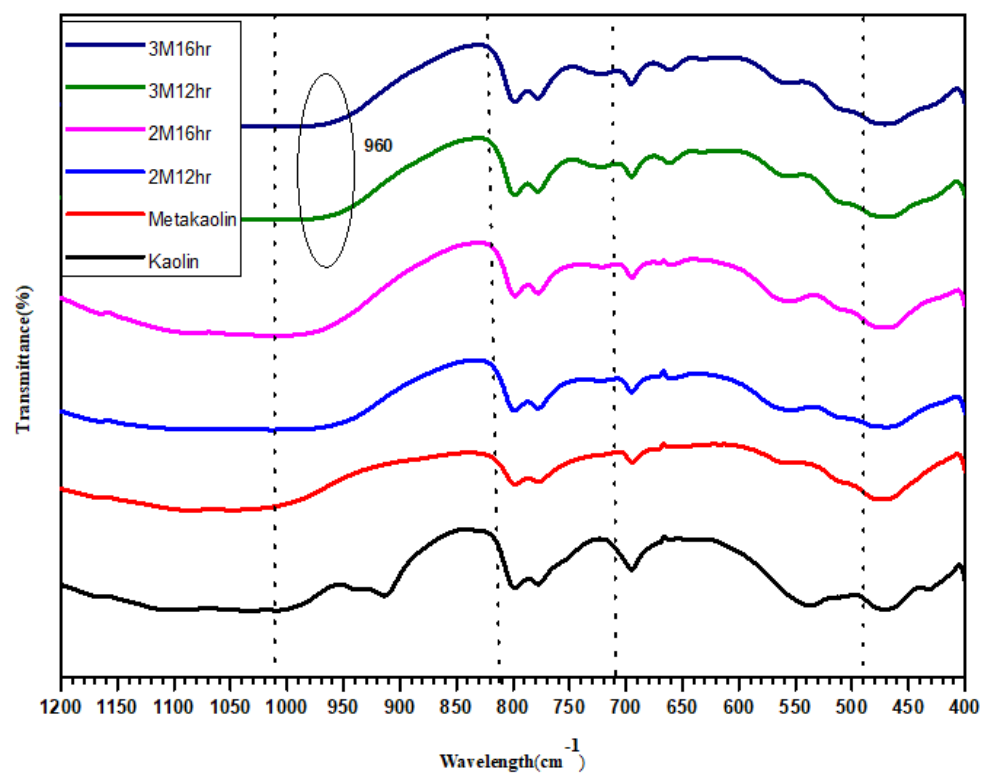

Figure 13. FTIR analysis of kaolin, metakaolin, and synthesis sodalite.

\subsubsection{Field emission scanning electron microscopy (FESEM) analysis.}

The analysis of FESEM was conducted to provide knowledge about the morphology of crystals and the process of crystal growth. The following morphologies in the as-synthesized sodalite have been observed using kaolinite as a starting material. There was no well-developed sodalite in the overall picture by FESEM analysis. Note that there was a spherical aggregate of SOD on the metakaolinite surface that has grown out. Figure 14(i), which involved $2 \mathrm{M} \mathrm{NaOH}$ and 12 hours of crystallization time, did not show sodalite formation and little formation on concrenite. There was a slight amount of sodalite that developed on the surface of metakaolinite in Figure 14 (ii). Figure 14 (iii) and (iv) demonstrate the rise in SOD attachment to residual metakaolinite on stable spherical crystallites. There were no needle-like SOD crystals found. The literature also found various forms of SOD morphologies [48] where the morphology was determined by many influences, such as $\mathrm{NaOH}$ concentration, anion form, $\mathrm{Si} / \mathrm{Al}$ ratio, and salinity. By a thorough transformation of zeolite A [76,77], a combination of cancrinite and sodalite was obtained. There are also have been recognized that at higher crystallization temperatures and/or after longer heating times, zeolite A was substituted by hydroxy-sodalite [78]. 

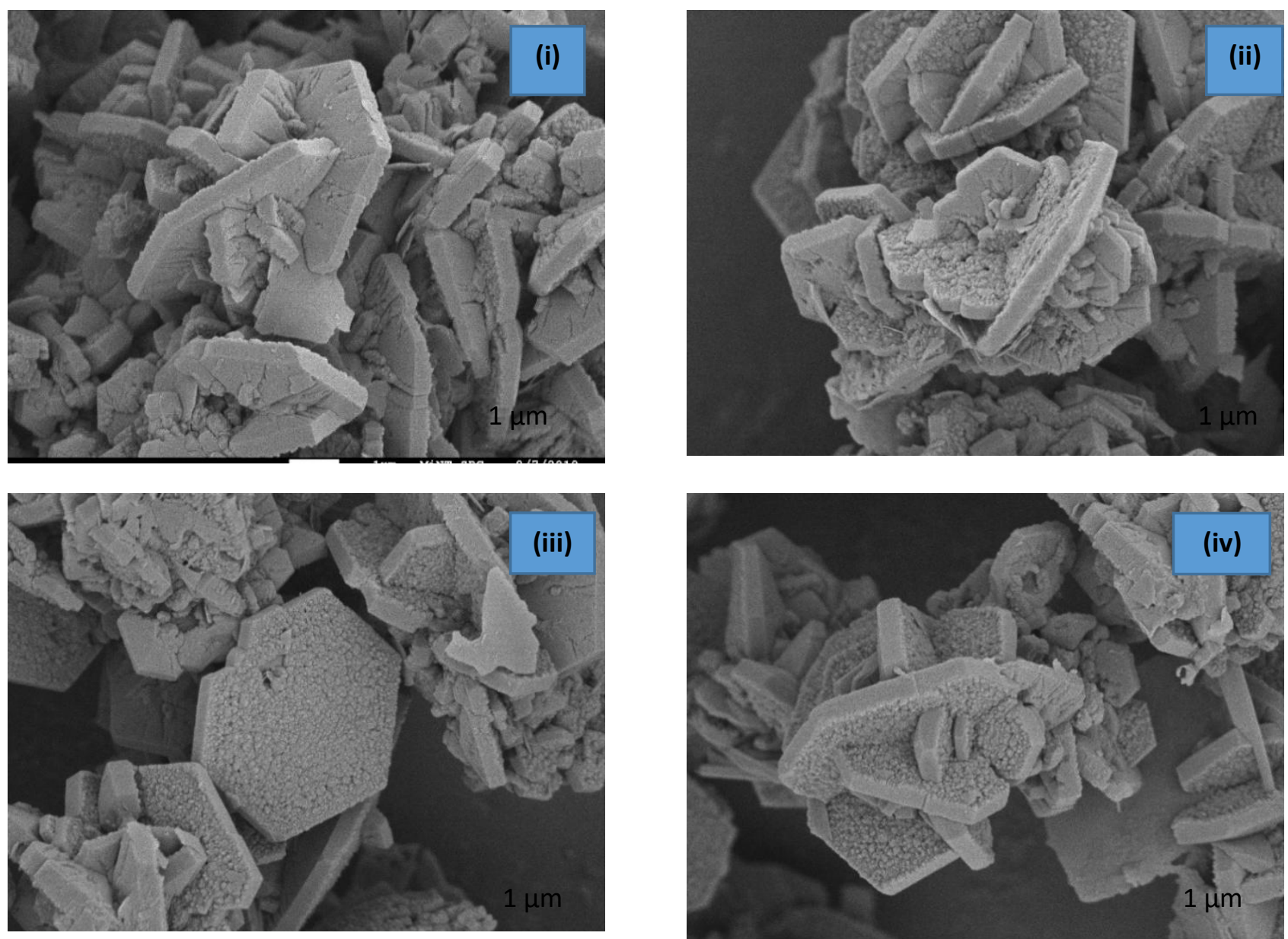

Figure 14. FESEM image of synthesis sodalite (i) $2 \mathrm{M} \mathrm{NaOH}, 12$ Hour crystallization time; (ii) $2 \mathrm{M} \mathrm{NaOH}, 16$ Hour crystallization time; (iii) $3 \mathrm{M} \mathrm{NaOH}, 12$ Hour crystallization time; (iv) $3 \mathrm{M} \mathrm{NaOH}, 16$ Hour crystallization time.

\section{Conclusions}

The ability of the SOD formation synthesized using low-grade kaolinite and metakaolinite as starting materials and $\mathrm{NaOH}$ as the triggering agent through hydrothermal treatment was investigated. The formation, however, was considered as reasonably ineffective by complete sodalite transformation, taking into account that the occurrence of SOD distinguished the region of synthesis products as a metastatic process. Metakaolinite and sodalite were the major phases obtained during the synthesis process. The synthesis materials heavily controlled the starting material, considering that metakaolinite is a more reactive phase than kaolinite. The reaction between the starting kaolinite and metakaolinite and alkaline solutions involved two main chemical processes: dissolution of the starting materials and crystallization. In order to illustrate the sequence of phase crystallization, future science should consider conducting further experiments under well-optimized.

\section{Funding}

This work was supported by the Ministry of Higher Education Malaysia and University Tun Hussein Onn Malaysia (UTHM) with FRGS grant Vot no FRGS/1/2018/TK05/UTHM/02/1. 


\section{Acknowledgments}

The authors would like to thank the Ministry of Higher Education, University Tun Hussein Onn Malaysia (UTHM), for the funding of the project.

\section{Conflicts of Interest}

The authors declare no conflict of interest.

\section{References}

1. Alessandro, F.G.; Paolo, A. The structure of K-hydrosodalite. Microporous and Mesoporous Materials 2006, 96, 276-286, https://doi.org/10.1016/j.micromeso.2006.07.010.

2. Ma, B.; Fernandez-Martinez, A.; Mancini, A.; Lothenbach, B. Spectroscopic investigations on structural incorporation pathways of FeIII into zeolite frameworks in cement-relevant environments. Cement and Concrete Research 2021, 140, 106304, https://doi.org/10.1016/j.cemconres.2020.106304.

3. Ferdi, S.; Sing, K.S.W.; Jens, W. Handbook of Porous Solids, Wiley-VCH, Weinheim, 2002, 3, 699.

4. Petersen, H.; Robben, L.; Gesing, T. On the nature of the phase transitions of aluminosilicate perrhenate sodalite. Zeitschrift für Kristallographie-Crystalline Materials 2020, 235, 213-223, https://doi.org/10.1515/zkri-2020-0027.

5. Xu, B.; Smith, P.; Wingate, C.; De Silva, L. The effect of calcium and temperature on the transformation of sodalite to cancrinite in Bayer digestion. Hydrometallurgy 2010, 105, 75-81, https://doi.org/10.1016/j.hydromet.2010.07.010.

6. Pauling, L. The Structure of Sodalite and Helvite. Zeitschrift fur Kristallographie 1930, 74, 213-225.

7. Chukanov,V.; Aksenov, S.W.; Rastsvetaeva, R.K. Structural chemistry, IR spectroscopy, properties, and genesis of natural and synthetic microporous cancrinite- and sodalite-related materials: A review. Microporous and Mesoporous Materials 2021, 323, 111098, https://doi.org/10.1016/j.micromeso.2021.111098.

8. Saehwa, C.; Brian, J, R.; Matthew, A.; Amanda, R. L.; Stephanie, H. B.; Junghune, N.; John, S, M.; Jarrod, V.C. Iodosodalite synthesis with hot isostatic pressing of precursors produced from aqueous and hydrothermal processes. Journal of Nuclear Materials 2020, 538, 152222, https://doi.org/10.1016/j.jnucmat.2020.152222.

9. Susan, E. L.; Joseph, S.; Bo B, I.; Jonathan, H.; Galen, D. S. Covalent Guest-Framework Interactions in Heavy Metal Sodalites: Structure and Properties of Thallium and Silver Sodalite. J. Phys. Chem. B 1999, 103, 7135-7144, https://doi.org/10.1021/jp990898i.

10. Smith, J.; Barrer, R.M. Zeolites and clay minerals as sorbents and molecular sieves. Mineralogical Magazine 1980, 43, 829-830, https://doi.org/10.1180/minmag.1980.043.330.29.

11. Teepakakorn, A.; Yamaguchi, T.; Ogawa, M. The Improved Stability of Molecular Guests by the Confinement into Nanospaces. Chemistry Letters 2019, 48, 398-409, https://doi.org/10.1246/cl.181026.

12. Yang, J.; Li, T.; Bao, X.;Yue, Y.; Liu, H. Mesoporogen-free synthesis of hierarchical sodalite as a solid base catalyst from sub-molten salt-activated aluminosilicate. Particuology 2020, 48, 48-54, https://doi.org/10.1016/j.partic.2018.07.005.

13. Fasolin, S.; Romano, M.; Boldrini, S.; Ferrario, A.; Fabrizio, M.; Armelao, L.; Barison, S. Single-step process to produce alumina supported hydroxy-sodalite zeolite membranes. Journal of Materials Science 2019, 54, 2049-2058, https://doi.org/10.1007\%2Fs10853-018-2952-6.

14. Kamyab, S.M.; Modabberi, S.; Williams, C.; Badiei, A. Synthesis of Sodalite from Sepiolite by Alkali Fusion Method and Its Application to Remove $\mathrm{Fe}^{3+}, \mathrm{Cr}^{3+}$, and $\mathrm{Cd}^{2+}$ from Aqueous Solutions. Environmental Engineering Science 2020, 37, 689-701, https://doi.org/10.1089/ees.2019.0492.

15. Choy, J.H.; Lee, S.R.; Han, Y.S.; Park, M.; Park, G.S. Solid-solid transformation mechanism for nanocrystalline sodalite from pillared clay. Chem. Commun. 2003, 1922-1923, https://doi.org/10.1039/B304638A.

16. Lee, S.R.; Park, M.; Han, Y.S.; Choy, J.H. Solid-solid transformation route to nanocrystalline sodalite from Al-PILC at room temperature. J. Phys. Chem. Solid 2004, 65, 421-424, https://doi.org/10.1016/j.jpcs.2003.09.013.

17. Baccouche, A.; Srasra, E.; El Maaoui, M. Preparation of Na-P1 and sodalite octahydrate zeolites from interstratified illite- smectite. Appl. Clay Sci 1998, 13, 255-273, https://doi.org/10.1016/S01691317(98)00028-3.

18. Shackelford, J.F.; Doremus, R.H. Ceramic and Glass Materials: 27 Structure, Properties and Processing. Springer, 2008, 28. 
19. Shackelford, J.F.; Doremus, R.H. Ceramic and glass materials : structure, properties and processing. Material Science 2008, http://dx.doi.org/10.1007/978-0-387-73362-3, http://dx.doi.org/10.1007/978-0-387-73362-3.

20. Chun, H.Z.; Li, Z.Z.; Ai, Q.W.; Tian, H.C.; Hong, P.H. Current fundamental and applied research into clay minerals in China. Applied Clay Science 2016, 119, 3-7, https://doi.org/10.1016/j.clay.2015.07.043.

21. Kovo, A. S.; Edoga, M. O. Production and characterisation of zeolite from Ahako clay in Kogi State, Nigeria. Leonardo Electronic Journal of Practices and Technologies 2005, 7, 31-40.

22. Abdullahi, T.; Harun, Z.; Hafiz, M.; Othman, D. A review on sustainable synthesis of zeolite from kaolinite resources via hydrothermal process. Adv. Powder Technol. 2017, 28, 1827-1840, https://doi.org/10.1016/j.apt.2017.04.028.

23. Temuujin, J.; Okada, K.; MacKenzie, K.J.D. Zeolite formation by hydrothermal treatment of waste solution from selectively leached kaolinite. Mater. Lett 2002, 52, 91-95, https://doi.org/10.1016/S0167$577 \mathrm{X}(01) 00372-\mathrm{X}$.

24. Yuan, H.; Shengwei, T.; Shaohua, Y.; Shiwei, L. Research progress on green synthesis of various high-purity zeolites from natural material-kaolin. Journal of Cleaner Production 2021, 306, https://doi.org/10.1016/j.jclepro.2021.127248.

25. Murukutti, M.K.; Jena, H. Synthesis of nano-crystalline zeolite-A and zeolite-X from Indian coal fly ash, its characterization and performance evaluation for the removal of $\mathrm{Cs}+$ and $\mathrm{Sr} 2+$ from simulated nuclear waste. Journal of Hazardous Materials 2022, 423, https://doi.org/10.1016/j.jhazmat.2021.127085.

26. Belviso, C.; Cavalcante, F.; Niceforo, G.; Lettino, A. Sodalite, faujasite and A-type zeolite from 2:1 dioctahedral and 2:1:1 trioctahedral clay minerals. A singular review of synthesis methods through laboratory trials at a low incubation temperature. Powder Technol 2017, 320, 483-497, https://doi.org/10.1016/j.powtec.2017.07.039.

27. Passos F.A.C.M., Castro, D.C., Ferreira, K.K., Simões, K.M.A., Bertolino, L.C., Barbato, C.N., Garrido, F.M.S.,Felix , A.A.S., Silva, F.A.N.G,.Synthesis and characterization of sodalite and cancrinite from kaolin, In book: Characterization of Minerals, Metals, and Materials 2017, 279-288, https://doi.org/10.1007/978-3319-51382-9_31.

28. Noel Essey, N.; Emmanuel, J.; Alexandra, C.; Erwan, P.; Marilyne, S.; Olivier, G.; Valentin, R.; Coelho Diogo, C.; Delphine, V.; Pascale, L.; Patrice, F.; Sylvie, R.; Nathalie, T.; Xavier, B. Role of cations on the dissolution mechanism of kaolinite in high alkaline media. Applied Clay Science 2021, 205, 106037 , https://doi.org/10.1016/j.clay.2021.106037.

29. Sruthi, P.L.; Reddy, H.P. Characterization of kaolinitic clays subjected to alkali contamination. Appl. Clay Sci 2017, 146, 535-547, https://doi.org/10.1016/j.clay.2017.07.012.

30. BSI, BS 1377-2, Methods of Test for Soils for Civil Engineering Purposes, British Standards Institution, Milton Keynes, UK, Classification tests 1990.

31. Johnson, E.B.G.; Arshad, S.E. Hydrothermally synthesized zeolites based on kaolinite: A review. Applied Clay Science 2014, 97-98, 215-221, https://doi.org/10.1016/j.clay.2014.06.005.

32. Chandrasekhar, S.; Pramada, P. N. Kaolin-based zeolite Y, a precursor for cordierite ceramics. Applied Clay science 2004, 27, 187-198, https://doi.org/10.1016/j.clay.2004.07.001.

33. Kulprathipanja, S. Zeolite in industrial separation and catalysis, 1st Ed; John Wiley \& Son, Inc. 2010.

34. Lutz, W. Zeolite Y: Synthesis, Modification, and Properties- A Case Revisited. Advances in Material Science and Engineering 2014, 640, 577-581, https://doi.org/10.1155/2014/724248.

35. Yahaya, S.; Jikan, S.S.; Badarulzaman, N. A.; Adamu, A.D. Chemical Composition and Particle Size Analysis of Kaolin. Path of Science 2017, 3, 1001-1004, https://doi.org/10.22178/pos.27-1.

36. Chee, L. C.; Ahmad, Z. A.; Sew, S. S. Relationship between the thermal behavior of the clays and their mineralogical and chemical composition: Example of Ipoh, Kuala Rompin and Mersing (Malaysia). Applied Clay Science 2017, 143, 327-335, https://doi.org/10.1016/j.clay.2017.03.037.

37. Osipov, V.I.; Sergeev, E.M. Crystallochemistry of clay minerals and their properties. Bulletin of the International Association of Engineering Geology 1972, 5, 9-15.

38. Ariffin, K. S.; Abdul Rahman, H.; Hussin, H.; Abdul hadi, K. A. The genesis and characteristics of primary kaolinitic clay occurrence at Bukit Lampas, Simpang Pulai, Ipoh. Bulletin of the Geological Society of Malaysia 2008, 54, 9-16, https://doi.org/10.7186/bgsm54200802.

39. Belviso, C.; Cavalcante, F.; Lettino, A.; Fiore, S. Zeolite synthesised from fused coal fly ash at low temperature using seawater for crystallization. Coal Combustion and Gasification Products 2009, 1, 8-13.

40. Baioumy, H. \& Ibrahim, A. Z. Mineralogical Variations among the Kaolin Deposits in Malaysia. Annual International Conference on Geological and Earth Science. National University of Singapore 2012, 133-140.

41. Ajala, A. J. A Study on Thermal Conductivity of Six Unexplored Nigerian Clays for Possible Rereactory and Insulating Materials. PhD. Thesis. Universiti Tun Hussein Onn Malaysia 2017. 
42. Andrejkovicova, S.; Madejova, J.; Czímerova, A.; Galko, I.; Dohrmann, R.; Komadel, P. Mineralogy and chemistry of Fe-rich bentonite from the Lieskovec deposit (Central Slovakia). Geologica Carpathica 2006, 57, 371-378.

43. Gilmore, C. Material Science and Engineering properties. SI Ed. Cengage 2015, 704.

44. Musyoka, N. M.; Missengue, R.; Kusisakana, M.; Petrik, L. F. Conversion of South African clays into high quality zeolites. Applied Clay Science 2014, 97-87, 182-186, https://doi.org/10.1016/j.clay.2014.05.026.

45. Ni, Y.; Zuo-Cai, Z.; Ning, M.; Huan-Li, L.; Xue-Qing, Z.; Bing, L.; Wei, G.; Fang-Chang, T.; Tao, J.; ChangJung, C.; Tai-Chin, C.; Dean, S. Effect of surface modified kaolin on properties of polypropylene grafted maleic anhydride. Results in Physics 2017, 7, 969-974, https://doi.org/10.1016/j.rinp.2017.02.030.

46. Kovo, A.S.; Holmes, S.M. Effect of Aging on the Synthesis of Kaolin-Based Zeolite Y from Ahoko Nigeria Using a Novel Metakaolinization Technique. Journal of Dispersion Science and Technology 2010, 31, 37-41, https://doi.org/10.1080/01932690903210218.

47. Loiola, A. R.; Andrade, J. D. R. A.; Sasaki, J.M.; Silva, L.R.D. Structural analysis of zeolite NaA synthesized by a cost-effective hydrothermal method using kaolin and its use as water softener. Journal of Colloid and Interface Science 2012, 367, 34-39, https://doi.org/10.1016/j.jcis.2010.11.026.

48. Musyoka, N.M.; Petrik, L.F.; Fatoba, O.O.; Hums, E. Synthesis of zeolites from coal fly ash using mine waters. Minerals Engineering 2013, 53, 9-15, https://doi.org/10.1016/j.mineng.2013.06.019.

49. Bahng, M.; Mukarakate, C.; Robichaud, D. J.; Nimlos, M. R. Current technologies for analysis of biomass thermochemical processing: A review. Analytica Chimica Acta 2009, 651, 117-138, https://doi.org/10.1016/j.aca.2009.08.016.

50. Johari, I.; Said, S.; Hisham, B.; Bakar, A.; Ahmad, Z. A. Effect of the change of firing temperature on microstructure and physical properties of clay bricks from Beruas (Malaysia). Science of Sintering 2010, 42, 245-254, https://doi.org/10.2298/SOS1002245J.

51. Kubiliute, R.; Kaminskas, R. The Pozzolanic Activity of Calcined Clay-Silica Gel Composites. Material science 2013, 19, 453-460, https://doi.org/10.5755/j01.ms.19.4.2300.

52. Covarrubias, C.; Garcia, R.; Yanez, J.; Garland, M.T. Cr (III) exchange on zeolites obtained from kaolin and natural mordenite. Microporous mesoporous Material 2006, 88, 220-231, https://doi.org/10.1016/j.micromeso.2005.09.007.

53. Kovo, A. S.; Edoga, M. O. Production and characterisation of zeolite from Ahako clay in Kogi State, Nigeria. Leonardo Electronic Journal of Practices and Technologies 2005, 7, 31-40, https://citeseerx.ist.psu.edu/viewdoc/download?doi=10.1.1.300.3209\&rep=rep1\&type=pdf.

54. Shafiq, N.; Nuruddin, M. F.; Khan, S. U.; Ayub, T. Calcined kaolin as cement replacing material and its use in high strength concrete. Construction and Building Material 2015, 81, 313-323, https://doi.org/10.1016/j.conbuildmat.2015.02.050.

55. Kovo, A. S. Effect of Temperature on the Synthesis of Zeolite X from Ahoko Nigerian kaolin using novel metakaolinization technique. Chemical Engineering Communication 2012, 199, 786-797, https://doi.org/10.1080/00986445.2011.625065.

56. Feltrin, A. C.; Souza, H. M.; Aquino, T. F.; Marques, C. R. M.; Angioletto, E. Synthesis and ion exchange of zeolites produced from kaolin for separation of oxygen from atmospheric air. International Journal of Applied Ceramic Technology 2021, 18, 1725-1733, https://doi.org/10.1111/ijac.13744.

57. Chandrasekhar, S. Influence of Metakaolinization temperature on the formation of Zeolite 4A from kaolin. Clay Minerals 1996, 31, 253-261, https://doi.org/10.1180/claymin.1996.031.2.11.

58. Feng, H.; Li, C.; Shan, H. Effect of Calcination Temperature of Kaolin Microspheres on the in situ Synthesis of ZSM-5. Catalysis Letter 2009, 129, 71-78, https://doi.org/10.1007/s10562-008-9794-9.

59. Padilla, J.; Guzman, A.; Molina-V, D.; Poveda, J. Structural transformation of kaolin as an active matrix for the in-situ synthesis of zeolite Y. Clay Minerals 2020, 55, 1-28, https://doi.org/10.1180/clm.2020.40.

60. El-Diadamony, H.; Amer, A.; Sokkary, T. M.; El-Hoseny, S. Hydration and characteristics of metakaolin pozzolanic cement pastes. Housing and Building National Research Center 2016, 14, 1-9, https://doi.org/10.1016/j.hbrcj.2015.05.005.

61. Murat, M.; Amokrane, A.; Mindrale, D.T. Synthesis of Zeolites from Thermally Activated Kaolinite. Some Observations on Nucleation and Growth. Clay mineral 1992, 27, 119-130, https://doi.org/10.1180/claymin.1992.027.1.12.

62. Brindley, G. W.; Nakahira, M. The Kaolinite-MuIlite Reaction Series: II, Metakaolin. Journal of the American Ceramic Society 1958, 42, 314-318, https://doi.org/10.1111/j.1151-2916.1959.tb14315.x .

63. Granizo, M. L.; Alonso, S.; Blanco-Varela, M. T.; Palomo, A. Alkaline Activation of Metakaolin: Effect of Calcium Hydroxide in the Products of Reaction. Journal of American Ceramic Society 2004, 85, 225-231, https://doi.org/10.1111/j.1151-2916.2002.tb00070.x. 
64. Ajayi, O. A.; Adefila, S. S.; Ityokumbul, M. T. Monitoring zeolite NaY formation from potassium-rich Nigerian kaolinite clay. Ain Shams Engineering Journal 2018, 9, 1653-1661, https://doi.org/10.1016/j.asej.2016.10.008.

65. Bahgaat, A.; Mohamed, M.; Karim, A.; Melegy, A.; Hassan, H. Synthesis and Characterization of Zeolite-Y from natural clay of Wadi Hagul, Egypt. Egyptian Journal of Chemistry 2020, 63, 3791-3800, https://doi.org/10.21608/ejchem.2020.23195.2378.

66. Mazur, M.; Wheatley, P. S.; Navarro, M.; Roth, W. J.; Polozij, M. Synthesis of 'unfeasible' zeolites. Nature Chemistry 2016, 8, 58-62, https://doi.org/10.1038/nchem.2374.

67. Erlebach, A., Nachtigall, P., \& Grajciar, L. Accurate large-scale simulations of siliceous zeolites by neural network potentials. 2021.

68. Petrov, I.; Michalev, T. Synthesis of Zeolite A: A Review. Scientific 2012, 51, 30-35, http://citeseerx.ist.psu.edu/viewdoc/download?doi=10.1.1.1049.109\&rep=rep1\&type=pdf.

69. Rozhkovskaya, A.; Rajapakse, J.; Millar, G.J. Synthesis of high-quality zeolite LTA from alum sludge generated in drinking water treatment plants. Journal of environmental chemical engineering 2021, 9, 104751, https://doi.org/10.1016/j.jece.2020.104751.

70. Sathupunya, M.; Gulari, E.; Wongkasemjit, S. ANA and GIS zeolite synthesis directly from alumatrane and silatrane by sol-gel process and microwave technique. Journal of European Ceramic Society 2002, 22, 23052314, https://doi.org/10.1016/S0955-2219(02)00042-0.

71. Khaleque, Md.; Alam, M.; Hoque, M.; Mondal, S.; Haider, J.; Johir, Md. A. b.; Karmakar, A.; Zhou, J.; Moni, M. A. Zeolite synthesis from low-cost materials and environmental applications: A review. Environmental Advances 2020, 2, 100019, https://doi.org/10.1016/j.envadv.2020.100019.

72. Barnes, M. C.; Addai-Mensah, J.; Gerson, A.R. The solubility of sodalite and cancrinite in synthetic spent Bayer liquor. Colloids and Surfaces A: Physicochemical and Engineering Aspects 1999, 157, 106-116, https://doi.org/10.1016/S0927-7757\%2899\%2900058-8.

73. Pan, X.; Wu, H.; Yu, H.; Bi, S.W. Precipitation of desilication products in CaO-Na2O-Al2O3-SiO2-H2O system based on the Bayer process. Hydrometallurgy 2020, 197, 105469.

74. Aronne, A.; Esposito, S.; Pernice. P. FT-IR and DTA study of lanthanum aluminosilicates glasses. Materials Chemistry and Physics 1997, 51, 163-168.

75. Cui, J.; Cao, X.; Shi, L.; Zhong, Z.; Gao, Q. A study of (71.5-x) SiO2-xAl2O3-11.5R2O-17RO glass system: Batch reaction process, structure and properties. Materials Chemistry and Physics 2021, 272, 125022, https://doi.org/10.1016/j.matchemphys.2021.125022.

76. Deng,Y.; Harsh, J.B.; Flury, M.; Young, J.S.; Boyle,J.S. Mineral formation during simulated leaks of Hanford waste tanks. Applied Geochemistry 2006, 21, 1392-1409, https://doi.org/10.1016/j.apgeochem.2006.05.002.

77. Hums,E., Inayat, A.; Schwieger, W. Presentation, 18th International Zeolite Conference, Rio, Brazil, 2016.

78. Hums, E. Synthesis of Phase-Pure Zeolite Sodalite from Clear Solution Extracted from Coal Fly Ash. J Thermodyn Catal 2017, 8, 187, https://doi.org/10.4179/2157-7544.1000187. 